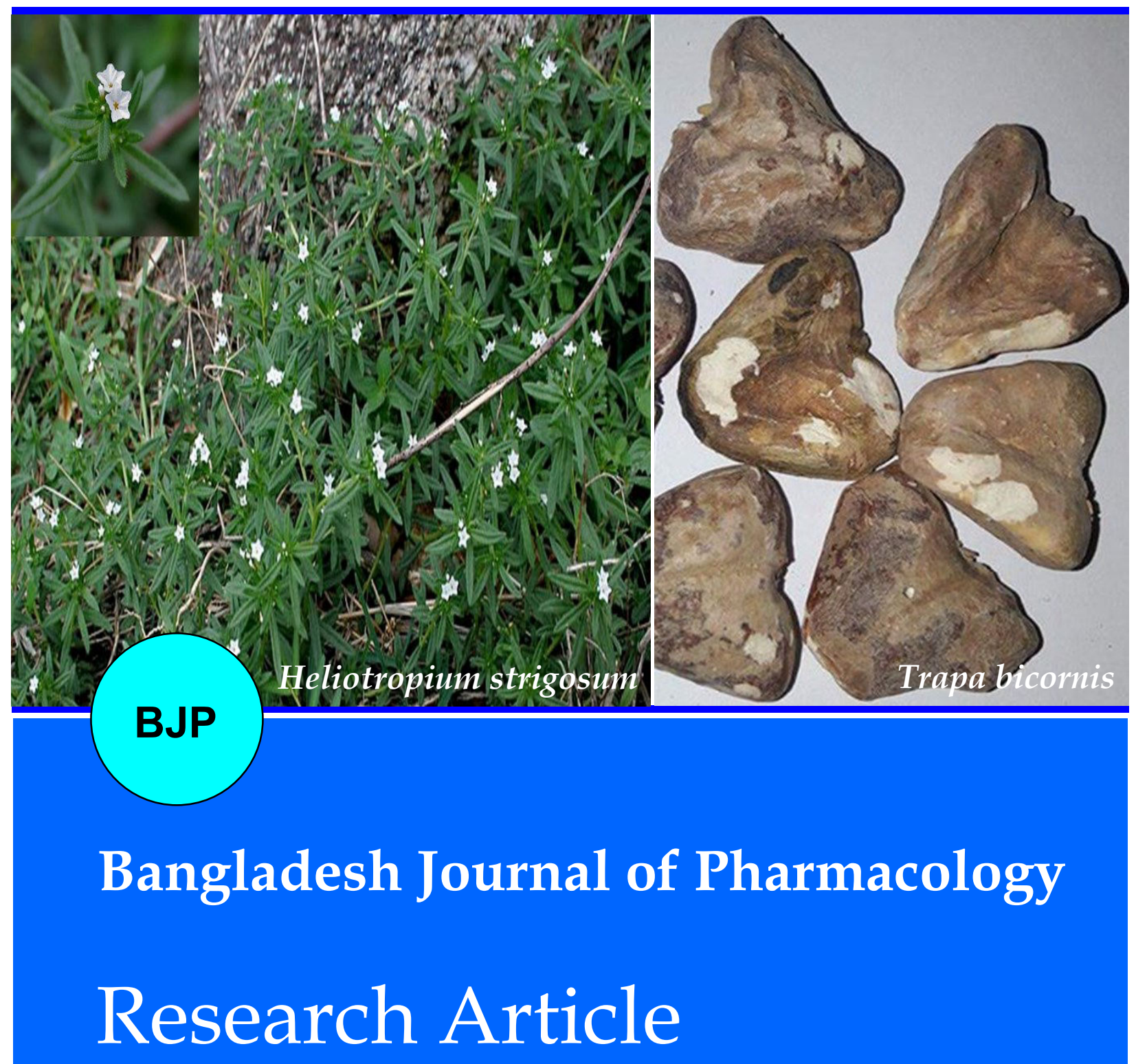


Abstracted/indexed in Academic Search Complete, Asia Journals Online, Bangladesh Journals Online, Biological Abstracts, BIOSIS Previews, CAB Abstracts, Current Abstracts, Directory of Open Access Journals, EMBASE/Excerpta Medica, Google Scholar, HINARI (WHO), International Pharmaceutical Abstracts, Open J-gate, Science Citation Index Expanded, SCOPUS and Social Sciences Citation Index;

ISSN: $1991-0088$

\title{
Effects of Heliotropium strigosum and Trapa bicornis in hyperactive gut disorders
}

\author{
Anam Saeed', Fazli Wahid'², Hafiz Majid Rasheed', Rahila Qayyum', Abdul Jabbar Shah' \\ and Taous Khan'
}

${ }^{1}$ Department of Pharmacy, COMSATS Institute of Information Technology, Abbottabad 22060, Pakistan; ${ }^{2}$ Biotechnology Program, Department of Environmental Sciences, COMSATS Institute of Information Technology, Abbottabad 22060, Pakistan.

\begin{tabular}{|c|c|}
\hline \multicolumn{2}{|l|}{ Article Info } \\
\hline $\begin{array}{l}\text { Received: } \\
\text { Accepted: } \\
\text { Available Online: }\end{array}$ & $\begin{array}{r}24 \text { February } 2017 \\
6 \text { June } 2017 \\
10 \text { June } 2017\end{array}$ \\
\hline DOI: $10.3329 /$ bjp. & $2 \mathrm{i} 2.31694$ \\
\hline $\begin{array}{l}\text { Cite this article: } \\
\text { Khan T, Saeed A, } \\
\text { HM, Qayyum R, } \\
\text { Heliotropium strigo } \\
\text { nis in hyperacti } \\
\text { Bangladesh J Phar } \\
\text {-96. }\end{array}$ & $\begin{array}{l}\text { Wahid F, Rasheed } \\
\text { hah AJ. Effects of } \\
\text { ım and Trapa bicor- } \\
\text { e gut disorders. } \\
\text { acol. 2017; 12: } 190\end{array}$ \\
\hline
\end{tabular}

\begin{abstract}
The current study was aimed to investigate the extracts from Heliotropium strigosum and Trapa bicornis phytochemically for various constituents and pharmacologically for gastro-intestinal disorders. Phytochemical analysis indicated the presence of alkaloids, flavonoids, glycosides and tannins in both the extracts. In castor oil-induced diarrhea, H. strigosum and T. bicornis, at 100$1000 \mathrm{mg} / \mathrm{kg}$ dose provided protection of $10-83 \%$ and $14-76 \%$ respectively. In isolated rabbit jejunum preparations, T. bicornis $(0.01-5 \mathrm{mg} / \mathrm{mL})$ relaxed the spontaneous and $\mathrm{K}^{+}(80 \mathrm{mM})$-induced contractions with $\mathrm{EC}_{50}$ values of 1.2 $\mathrm{mg} / \mathrm{mL}$ and $2.6 \mathrm{mg} / \mathrm{mL}$ respectively, suggesting that spasmolytic effect was possibly mediated through calcium channel blockade. This was further authenticated when pretreatment of tissues with $T$. bicornis $(1-5 \mathrm{mg} / \mathrm{mL})$ caused rightward shift of $\mathrm{Ca}^{++}$concentration-response curves, similar to verapamil. In acute toxicity test, both extracts were safe up to $10 \mathrm{~g} / \mathrm{kg}$ dose. These results indicated the usefulness of H. strigosum and T. bicornis in the treatment of hyperactive gut disorders.
\end{abstract}

\section{Introduction}

Heliotropium strigosum (family; Boraginaceae), locally known as Gorakh pan or Panjabooti, has folkloric medicine uses in the diarrhea, gum boils, sore eyes, and insects and snake bite (Hussain et al., 2010). It has been reported as anti-oxidant (Modak et al., 2007), antimicrobial (Hussain et al., 2010), antinociceptive, anticonvulsant and anti-inflammatory (Khan et al., 2013). Phytochemical analysis of Heliotropium showed the presence of strigosine (pyrrolizidine) and necine (trachelanthamidine, supinidine and retronecine) alkaloids in most species (Mattocks, 1964). Trachelanthamidine and 3 phthalic acid esters have been isolated from $H$. strigosum. Similarly, chromotropic acid, quercetin, trans -4-hydroxy-3-methoxy cinnamic acid, vanillic acid, gallic acid, caffeic acid, m-coumaric acid, $p$-coumaric acid, syringic acid, sinapic acid and ferulic acid have also been detected in this plant (Qayyum et al., 2016).

Trapa bicornis (family; Lythraceae), locally known as Singhara, is used in the gastrointestinal, thyroid and cardiovascular disorders, bronchitis, diabetes mellitus, and gout (Rahman et al., 2001). It possesses analgesic (Agrahari et al., 2010), anti-inflammatory (Patel et al., 2010), antidiabetic (Das et al., 2011) and antimicrobial (Parekh and Chandana, 2007) activities. Carbohydrates, phytosterols, saponins, fixed oils, fat, tannins, flavonoids and glycosides have been reported in this plant (Bhatiwal et al., 2012).

Although these plants are used in traditional medicine for the treatment of different gastrointestinal disorders, no scientific information are available regarding the use of H. strigosum (in diarrhea) and T. bicornis (in diarrhea 
and gut spasms). Therefore, the current study was undertaken to explore the pharmacological basis of these plants in hyperactive gut disorders using in vivo and in vitro approaches.

\section{Materials and Methods}

\section{Plant material}

H. strigosum was collected from Bhakkar District, Punjab, Pakistan while T. bicornis was purchased from the local market. The plants were authenticated by Dr. Abdul Nazir, Department of Environmental Sciences, COMSATS Institute of Information Technology, Abbottabad, Pakistan. The voucher specimen of $H$. strigosum (DB-GC (HSB)-0030) and T. bicornis (DB-GC (TBL)-0031) was deposited in the Department of Botany, Government Postgraduate College, Abbottabad, Pakistan.

\section{Processing and extraction}

The fresh plant was shade dried at ambient temperature. The dried plant material (300 g each) was pulverized and soaked in $1.5 \mathrm{~L}$ aqueous-methanol (70\%) for 15 days with occasional shaking. The extracts were, then, filtered through a muslin cloth and then through a Whatman filter paper. Similar protocol was also repeated thrice. The resultant filtrate was concentrated to a thick, semi-solid mass using rotary evaporator (HAHN VAPOR HS-2005S-N, Korea) coupled with an electric aspirator (HS-3000, Korea) and recirculation chiller (RW $-0525 \mathrm{G}$, Jiec Tech, Korea) at $45^{\circ} \mathrm{C}$ under reduced pressure.

\section{Drugs and standards}

Acetylcholine, potassium chloride, calcium chloride and verapamil were acquired from the Sigma Chemical Company (USA). Water solubility of the extracts was improved with $10 \%$ Tween 80 or dimethyl sulfoxide (DMSO). Castor oil was obtained from the Karachi Chemical Industries, Pakistan. The chemicals of maximum purity grade were used. Stock solutions were prepared in distilled water/suitable solvent and dilutions were made fresh on the day of experiment.

\section{Animals}

Balbc mice (20-25 g) were used for in vivo antidiarrheal experiments while male rabbits $(1-1.5 \mathrm{~kg})$ of local breed were purchased from the local market and used for in vitro studies. The animals used in current study were kept at the animal house of the Department of Pharmacy, CIIT, Abbottabad under controlled environment and were given standard diet and tap water ad libitum.

\section{Phytochemical analysis}

Preliminary screening for various groups of natural products
The crude extracts obtained from $H$. strigosum and $T$. bicornis were screened for the presence of saponins, flavonoids, tannins, phenols and alkaloids using the methods described elsewhere (Edeoga et al., 2005).

Thin layer chromatography (TLC)

TLC was used for the separation and analysis of different components of extracts. TLC plates coated with silica gel (60 F254) (Merck, Germany) were used for this purpose. $n$-Hexane : ethyl acetate (1:1) were used as mobile phase and the retardation factor ( $\mathrm{Rf}$ values) of various constituents were calculated using the following formula:

$\mathrm{Rf}=\frac{\text { Distance moved by substance }}{\text { Distance moved by solvent front }}$

Ultraviolet light (wavelength 254 and $365 \mathrm{~nm}$ ) was employed for UV active constituents of the extracts. The various constituents were also visualized on TLC using phosphomolybdic acid (10\%) and ceric sulfate as the locating reagents.

High Performance Liquid Chromatographic (HPLC) analysis

HPLC (Perkin Elmer Series 2000 auto samples) was used to detect the major components of extracts. Stock solution $(10 \mathrm{mg} / \mathrm{mL})$ of $H$. strigosum and T. bicornis were prepared in ethanol : water (60:40) and filtered with $0.45 \mu \mathrm{m}$ syringe filter. HPLC was performed using C18 column $(150 \times 4.6 \mathrm{~mm})$ and injection volume was $20 \mu \mathrm{L}$. The mobile phase (acetonitrile : water : acetic acid) in ratio $60: 39.5: 0.5$ and ultraviolet visible detector (200-700 nm) was used. The sample was injected at the rate of $1 \mathrm{~mL} / \mathrm{min}$.

\section{Acute toxicity test}

The acute toxicity assay was performed as described earlier using the mice model (Gilani et al., 2005). Briefly, the animals were divided into 7 groups (five mice/ group). Group I (negative control) was given normal saline at $10 \mathrm{~mL} / \mathrm{kg}$ dose. Group II-IV were given different doses of $H$. strigosum while Group V-VII were treated with different doses of T. bicornis. All the extract treated groups were given oral dose of 3,5 and $10 \mathrm{~g} / \mathrm{kg}$. The animals were given food and water ad libitum during the experiment and different effects like flatness, shivering and diarrhea were observed for 24 hours.

\section{Castor oil-induced diarrhea}

In vivo antidiarrheal activity of both extracts was performed on Balbc albino mice as described previously (Awouters et al., 1978; Shah et al., 2010). Animals were divided into 11 groups (5 mice/group) and kept in separate cages. Group I (vehicle control) was given normal saline. Group II was treated with castor oil and groups III-V were given doses of 100, 300 and $1000 \mathrm{mg} /$ $\mathrm{kg}$ of $H$. strigosum, respectively. Group VI-VIII were 
treated with T. bicornis at respective doses of 100, 300 and $1000 \mathrm{mg} / \mathrm{kg}$. Verapamil (standard drug) was orally administered at 1,3 and $10 \mathrm{mg} / \mathrm{kg}$ to Groups IX-XI, respectively. After 1 hours of the treatment, Groups IIIXI were treated with castor oil. The castor oil treated groups were observed for defecation after 4 hours of the oil administration. The protection percentage was determined by comparing wet and dry fecal count in each cage.

\section{Rabbit jejunum}

The rabbit jejunum preparations were used to determine possible spasmolytic activity following the previously reported protocols (Gilani et al., 2005; Shah et al., 2010). The rabbits were fasted for 24 hours before the experiments and sacrificed by cervical dislocation. The abdomen was cut open and jejunal portion was isolated. The video component of the methodology was published earlier (Rafique et al., 2016). About $2 \mathrm{~cm}$ long jejunum preparations were mounted in tissue baths containing Tyrode's solution $(10 \mathrm{~mL})$ maintained at $37^{\circ}$ $\mathrm{C}$ and continuously aerated with a mixture of $5 \%$ carbon dioxide in oxygen (carbogen). The composition of Tyrode's solution was (mM): $\mathrm{KCl} 2.7, \mathrm{NaCl} 136.9$, $\mathrm{MgCl}_{2} 1.1, \mathrm{NaHCO}_{3} 11.9, \mathrm{NaH}_{2} \mathrm{PO}_{4} 0.4$, glucose 5.6 and $\mathrm{CaCl}_{2} 1.8$ ( $\mathrm{pH} 7.4$ ). A preload of $1 \mathrm{~g}$ was applied to each tissue and was allowed to stabilize for $30 \mathrm{~min}$. Tissues were treated with a submaximal dose $(0.3 \mu \mathrm{M})$ of acetylcholine to attain control response and presumed stable after the reproducibility of said response. After stabilization, different concentrations of T. bicornis were added cumulatively and the response was calculated as a percent of control (untreated).

The calcium channel blocking activity was determined by depolarizing the tissues with a high dose of $\mathrm{K}^{+}(80$ $\mathrm{mM}$ ) (Farre et al., 1991). After plateau formation, $T$. bicornis was added in a concentration dependent manner to obtain concentration-dependent inhibitory curves (van Rossum, 1963). The inhibitory effect of the extract was calculated as percent of control response exhibited by high $\mathrm{K}^{+}$. The calcium channel blocking activity of T. bicornis was further confirmed by tissue stabilization in Tyrode's solution followed by replacement with $\mathrm{Ca}^{++}$-free Tyrode's solution containing ethylenediaminetetra-acetic acid (EDTA) $(0.1 \mathrm{mM})$. The solution was further replaced with $\mathrm{Ca}^{++}$-free and $\mathrm{K}^{+}$rich Tyrode's solution. Calcium response curves were obtained when tissue was pretreated with different concentrations of $T$. bicornis. The calcium response curves were reproduced and compared with control. Similar protocol was also performed for verapamil, a standard calcium channel blocking drug.

\section{Statistical analysis}

All the data expressed are mean \pm SEM, and the median effective concentrations ( $\mathrm{EC}_{50}$ values) are given with $95 \%$ confidence intervals. The statistical parameter applied was the Student's t-test with $\mathrm{p}<0.05$ noted as significantly different (GraphPad Prism, version 5).

\section{Results}

\section{Phytochemical analysis}

The crude extracts were subjected to primary phytochemical analysis to find out their chemical composition. Initial analysis of $H$. strigosum revealed the presence of alkaloids, glycosides, flavonoids, steroids, tannins and terpenoids while T. bicornis indicated the presence of alkaloids, glycosides, flavonoids, tannins and saponins. Saponins were absent in H. strigosum while T. bicornis was devoid of steroids and terpenoids. Quinones were absent in both the extracts (Table I).

\begin{tabular}{|lcc|}
\hline \multicolumn{3}{|c|}{ Table I } \\
\hline \multicolumn{3}{|c|}{ Phytochemicals analysis of H. strigosum and T. } \\
bicornis extracts \\
\hline $\begin{array}{l}\text { Phytochemical con- } \\
\text { stituents }\end{array}$ & Results \\
\hline Alkaloids & + & T. bicornis \\
Glycosides & + & + \\
Flavonoids & + & + \\
Saponins & - & + \\
Steroids & + & + \\
Tannins & + & + \\
Terpenoids & + & - \\
Quinones & - & + \\
\hline
\end{tabular}

\section{Chromatographic analysis}

TLC plates were developed for $H$. strigosum and $T$. bicornis. None of the components were located under UV-light for $H$. strigosum on TLC developed in the mentioned mobile phase. The components, however, became visible (Figure 1A) by spraying the TLC plate with ceric sulphate. Various constituents in T. bicornis were located on TLC using UV-light (254 and $365 \mathrm{~nm}$ ). No spot of constituents was visualized in 254 and 365 $\mathrm{nm}$ light but spraying the TLC plate with $10 \%$ molybdic acid clearly indicated the separation of the various components (Figure 1D). The Rf values of different compounds for H. strigosum and T. bicornis are shown in Figure $1 \mathrm{~B}$ and E, respectively.

HPLC analysis of $H$. strigosum at a wavelength of 271 $\mathrm{nm}$ displayed two major peaks at the retention time of 2.1 and $3.1 \mathrm{~min}$ (Figure 1C). The chromatogram for $T$. bicornis (at $267 \mathrm{~nm}$ ) also showed two major peaks at 1.9 and 3.1 min (Figure 1F), respectively.

\section{Acute toxicity test}

The results for $H$. strigosum and T. bicornis (3, 5 and 10 $\mathrm{g} / \mathrm{kg}$ ), administered to mice and observed for beha- 


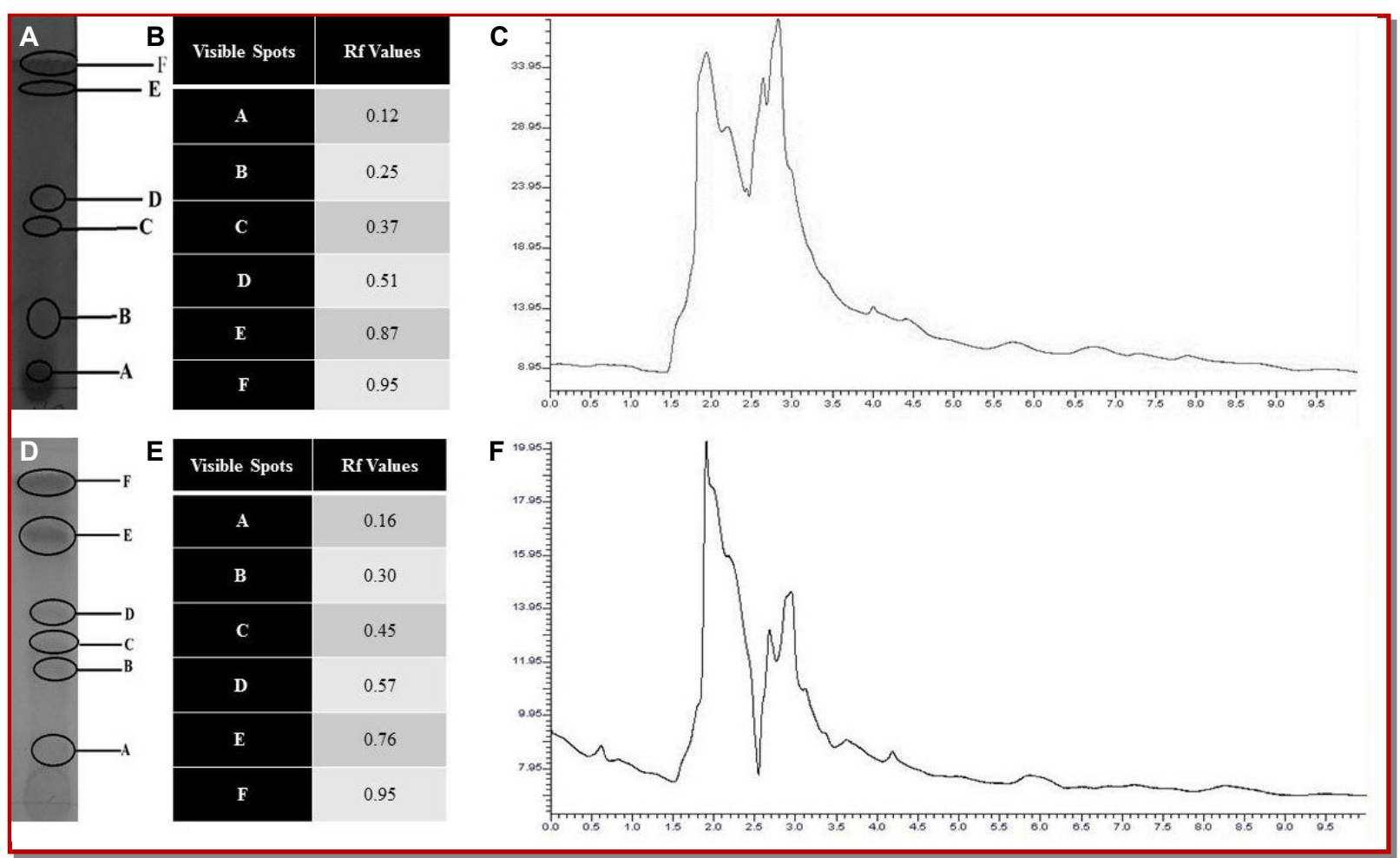

Figure 1: TLC and HPLC analysis of H. strigosum and T. bicornis crude extracts; (A) TLC chromatogram, (B) Rf values of the detected compounds, and (C) HPLC chromatogram of H. strigosum. (D-F) respectively, shows TLC chromatogram, Rf values of the detected compounds and HPLC chromatogram of T. bicornis

vioral changes and mortality for 24 hours, showed that both the extracts were safe up to $10 \mathrm{~g} / \mathrm{kg}$ dose, as no lethality was observed.

\section{Antidiarrheal activity}

The antidiarrheal activity of $H$. strigosum showed that it provided 10.3, 37.1 and $83.3 \%$ protection at 100, 300 and $1000 \mathrm{mg} / \mathrm{kg}$ doses, respectively (Table II). Similarly, $T$. bicornis displayed 14.2, 39.6 and $76.4 \%$ protection against diarrhea at respective similar doses (Table II). The results were compared with verapamil $(1,3$ and 10 $\mathrm{mg} / \mathrm{kg}$ ), a standard calcium channel blocker, which controlled diarrhea up to 31.6, 60.1 and $85.3 \%$, respectively (Table II).

\section{Spasmolytic effect of T. bicornis}

The spasmolytic effect of T. bicornis was tested on isolated rabbit jejunum strips. T. bicornis $(0.01-5 \mathrm{mg} / \mathrm{mL})$

\begin{tabular}{|lrccc|}
\hline \multicolumn{5}{c|}{ Table II } \\
\multicolumn{5}{|c|}{ Effect of the crude extract of H. strigosum and T. bicornis on castor oil-induced diarrhea in mice } \\
\hline Group & Dose & Total number of feces in 4 hours & Wet feces in 4 hours (\%) & Protection (\%) \\
\hline Control (saline) & $10 \mathrm{~mL} / \mathrm{kg}$ & $5.2 \pm 0.5$ & $0 \pm 0$ & $9.6 \pm 4.0$ \\
Castor oil & $10 \mathrm{~mL} / \mathrm{kg}$ & $16 \pm 0.7$ & $96.2 \pm 2.3$ & $2.6 \pm 2.3$ \\
H. strigosum & $100 \mathrm{mg} / \mathrm{kg}$ & $6.3 \pm 0.7$ & $76.0 \pm 1.0$ & $10.3 \pm 1.0$ \\
& $300 \mathrm{mg} / \mathrm{kg}$ & $5.0 \pm 1.5$ & $56.0 \pm 1.2$ & $37.1^{\mathrm{a}} \pm 0.6$ \\
& $1,000 \mathrm{mg} / \mathrm{kg}$ & $4.6 \pm 1.9$ & $20.4 \pm 1.8$ & $83.3^{\mathrm{c}} \pm 5.9$ \\
T. bicornis & $100 \mathrm{mg} / \mathrm{kg}$ & $10.2 \pm 3.2$ & $71.0 \pm 2.2$ & $14.2 \pm 4.9$ \\
& $300 \mathrm{mg} / \mathrm{kg}$ & $8.6 \pm 2.8$ & $53.6 \pm 2.0$ & $39.6^{\mathrm{a}} \pm 6.0$ \\
Verapamil & $1,000 \mathrm{mg} / \mathrm{kg}$ & $5.4 \pm 3.0$ & $27.2 \pm 0.9$ & $76.4^{\mathrm{b}} \pm 0.9$ \\
& $1 \mathrm{mg} / \mathrm{kg}$ & $8.4 \pm 0.6$ & $66.9 \pm 3.7$ & $31.6^{\mathrm{a}} \pm 3.3$ \\
& $3 \mathrm{mg} / \mathrm{kg}$ & $6.2 \pm 0.4$ & $47.2 \pm 5.0$ & $60.1^{\mathrm{b}} \pm 4.2$ \\
& $10 \mathrm{mg} / \mathrm{kg}$ & $4.2 \pm 0.2$ & $24.6 \pm 1.7$ & $85.3^{\mathrm{c}} \pm 6.0$ \\
\hline
\end{tabular}

$n=5$ in each case; Mean \pm SEM; a $<<0.05$, b $<<0.01$ and c $p<0.001$ vs control; Student's t-test 


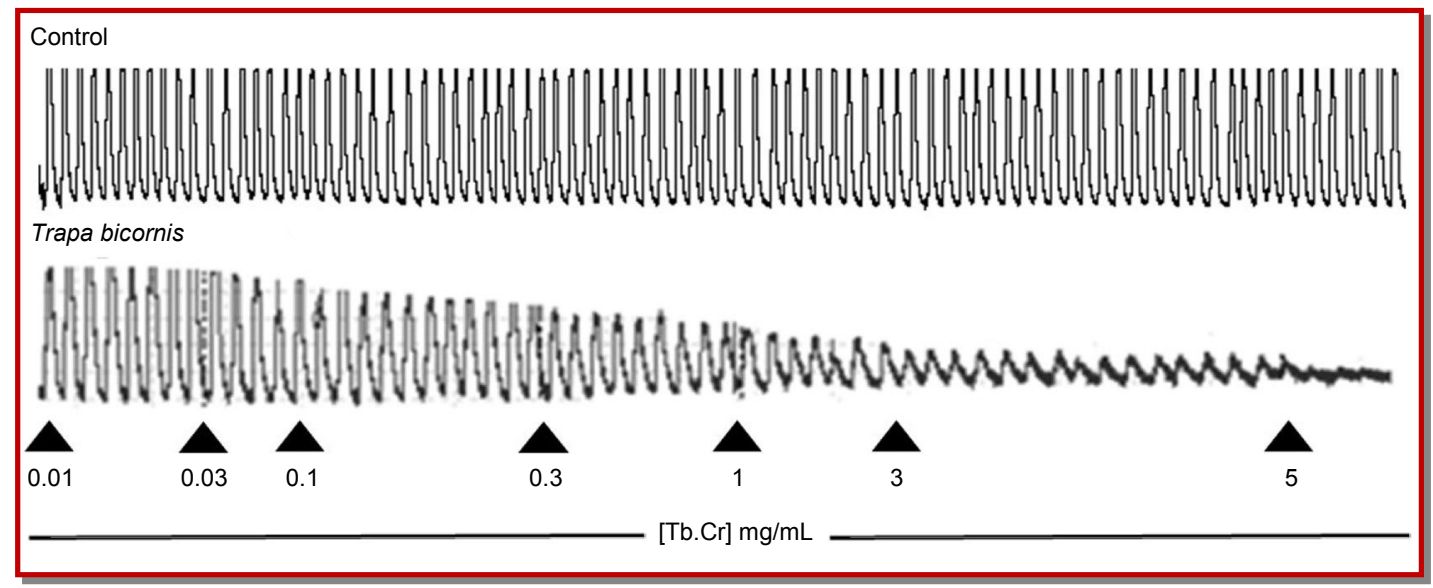

Figure 2: Tracing showing normal contraction and relaxation (control) of rabbit jejunum and relaxant effect of Trapa bicornis crude extract $(\mathrm{Tb} . \mathrm{Cr}$ ) on spontaneous contractions in isolated rabbit's jejunum preparation

suppressed the spontaneous (Figure 2$)$ and high $\mathrm{K}^{+}(80$ $\mathrm{mM}$ ) induced contractions (Figure $3 \mathrm{~A}$ ) in a dose-dependent fashion with $\mathrm{EC}_{50}$ values of $1.2 \mathrm{mg} / \mathrm{mL}$ (1-1.3) and $2.6 \mathrm{mg} / \mathrm{mL}$ (1-4.6), respectively. Verapamil also inhibited spontaneous and high $\mathrm{K}^{+}(80 \mathrm{mM})$ induced contrac- tions (Figure $3 \mathrm{~B}$ ) with respective $\mathrm{EC}_{50}$ values of $0.1 \mathrm{mg} /$ $\mathrm{mL}(0.1-0.13)$ and $0.02 \mathrm{mg} / \mathrm{mL}(0.01-0.03)$. Pretreatment of tissue with $T$. bicornis $(1-5 \mathrm{mg} / \mathrm{mL})$ shifted calcium concentration response curves towards right (Figure 3C) in a comparable manner to verapamil (Figure 3D).

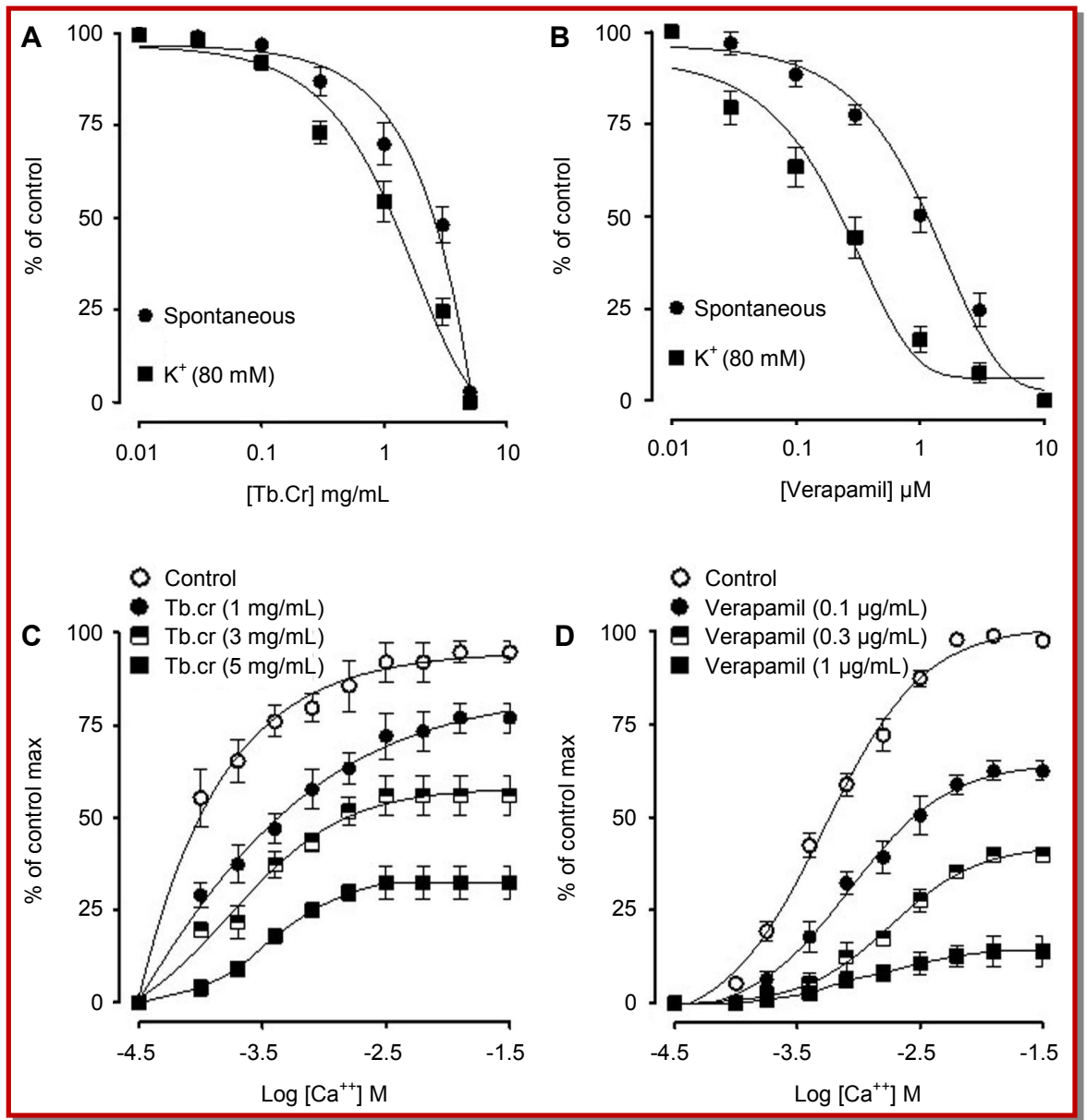

Figure 3: Graphical representation of (A) relaxant effect of Trapa bicornis crude extract (Tb.Cr), (B) verapamil on spontaneous and $\mathrm{K}^{+}$-induced contractions in isolated rabbit's jejunum preparation, $(\mathrm{C})$ concentration-response curves of calcium by different concentrations of T. bicornis, and (D) verapamil on isolated rabbit's jejunum preparation. Values shown are mean $\pm S E M(n=3)$ 


\section{Discussion}

H. strigosum and T. bicornis significantly inhibited the frequency of defecation as well as wetting of feces compared to the untreated group, the effect was similar to verapamil. The induction of diarrhea by castor oil results from the action of ricinoleic acid, which is formed by the action of lipase on triricinolein (a major constituent of the castor oil) in the duodenum. Ricinoleic acid in turn causes changes in the transport of water and electrolytes in the intestine and leads to a hypersecretory response and generation of a giant contraction of the intestine (Shah et al., 2010). A potential antidiarrheal agent may exhibit its effect by inhibiting the gut motility (spasmolytic) and/or electrolyte out flux in the form of wet droppings (Croci et al., 1997). The protective effect of $H$. strigosum and $T$. bicornis against the castor oil-induced diarrhea, similar to verapamil, suggests that these extracts may exert an inhibitory effect on contractions.

To have insight into the nature of effect on intestinal contractions (gut motility), the effects of T. bicornis was further studied in isolated rabbit jejunum preparation. Literature lacks spasmolytic studies on T. bicornis, however, $H$. strigosum is recently showed as antispasmodic with calcium channel blocking effect (Janbaz et al., 2015). Spontaneously beating isolated rabbit jejunum preparation is considered suitable for testing spasmolytic substances without use of a spasmogen (Gilani et al., 2005). Cumulative addition of T. bicornis suppressed the spontaneous contractions of rabbit jejunum, similar to that caused by verapamil, a standard calcium channel blocker (Godfraind et al., 1986). This suggests that T. bicornis induces inhibitory effect on intestinal smooth muscle contractions. However, further studies were carried out probing the underlying mechanism.

Contractions of smooth muscles including rabbit jejunum, is dependent on an increased intracellular concentration of free $\mathrm{Ca}^{++}$, which subsequently activate the contractile proteins (Karaki and Weiss, 1988). The intracellular $\mathrm{Ca}^{++}$concentration is elevated either by influx through voltage-dependent $\mathrm{Ca}^{++}$channels (VDCs) or discharge from the $\mathrm{Ca}^{++}$stores present in the sarcoplasmic reticulum. The spontaneous movements of the intestine are regulated by periodic depolarization and repolarization and the action potential appears as a rapid influx of $\mathrm{Ca}^{++}$through VDCs at the height of depolarization (Brading, 1981). Thus, the inhibitory effect of T. bicornis on spontaneous movements of rabbit jejunum may be due to an interference with $\mathrm{Ca}^{++}$influx through VDCs. Previously, it was observed that the spasmolytic constituents present in different medicinal plants mediate their effects usually through an inhibitory effect on $\mathrm{Ca}^{++}$movement (Gilani et al., 2005; Shah et al., 2010). In order to verify that the spasmolytic effect of T. bicornis is mediated through an inhibition on
$\mathrm{Ca}^{++}$influx via VDCs, the tissues were depolarized with a high concentration of $\mathrm{K}^{+}(80 \mathrm{mM})$ followed by the addition of the crude extract in a cumulative fashion. $T$. bicornis showed concentration dependent relaxation, similar to verapamil, suggesting that the spasmolytic effect is mediated through its inhibitory effect on $\mathrm{Ca}^{++}$ influx via VDCs. This hypothesis was further strengthened when pretreatment of the tissues with $T$. bicornis caused a rightward shift in the $\mathrm{Ca}^{++}$ concentration response curves, similar to verapamil. These results indicate that extract of $T$. bicornis possesses calcium channel blocking type constituents. Our findings provide pharmacological basis to the medicinal use of T. bicornis in hyperactive gut disorders, as calcium channel blockers are clinically useful in diarrhea and gut spasms (Brunton, 1996). Previously reported calcium channel blocking activity of the extract of $H$. strigosum supports our finding on its antidiarrheal potential.

Preliminary phytochemical analysis indicated presence of flavonoids, saponins, tannins, alkaloids and glycosides. Plant derived flavonoids (Zhu et al., 1997), saponins (Kai et al., 1998) and tannins (Zhu et al., 2005) have been found to possess calcium channel blocking effect, which might be the active candidate(s) responsible for the antidiarrheal and spasmolytic effect of T. bicornis and also H. strigosum. In the acute toxicity study both extracts were found safe up to $10 \mathrm{~g} / \mathrm{kg}$ dose.

\section{Conclusion}

The crude extracts of $H$. strigosum and T. bicornis possess various phytochemicals with antidiarrheal effects. Moreover, the crude extract from T. bicornis also showed antispasmodic effect possibly mediated through calcium channel blockade.

\section{Ethical Issue}

All animals were housed, cared and used according to the rulings of the Ethical Committee of CIIT, Abbottabad, which completely agreed with the recommendations of Institute of Laboratory Animal Resources, Commission on Life Sciences, National Research Council (National Research Council, 1996).

\section{Conflict of Interest}

All authors have completed the ICMJE uniform disclosure form and declare no support from any organization for the submitted work.

\section{References}

Agrahari AK, Khaliquzzama M, Panda SK. Evaluation of analgesic activity of methanolic extract of Trapa natans L. var. 
bispinosa Roxb roots. J Curr Pharm Res. 2010; 1: 8-11.

Awouters F, Niemegeers CJE, Lenaerts FM, Janssen PAJ. Delay of castor oil diarrhoea in rats, a new way to evaluate inhibitors of prostaglandin biosynthesis. J Pharm Pharmacol. 1978; 30: 41-45.

Bhatiwal S, Jain A, Chaudhary J. Trapa natans (water chestnut): An overview. Int Res J Pharm. 2012; 3: 31-33.

Brading AF. How do drugs initiate contraction in smooth muscles? Trends Pharmacol Sci. 1981; 2: 261-65.

Brunton LL. Agents affecting gastrointestinal water flux and motility; emesis and antiemetics; bile acids and pancreatic enzymes. In: Goodman and Gillman's The Pharmacological basis of therapeutics. Hardman JG, Limbird LE, Molinoff PB (eds). 9th ed. New York, McGraw Hill, 1996.

Croci T, Landi M, Edmonts- Alt X, Le Fur G, Maffrand JP, Manara L. Role of trachykinins in castor oil diarrhea in rats. Br J Pharmacol. 1997; 121: 375-80.

Das PK, Bhattacharya S, Pandey JN, Biswas M. Antidiabetic activity of Trapa natans fruit peel extract against streptozotocin-induced diabetic rats. Global J Pharmacol. 2011; 5: 186-90.

Edeoga H, Okwu D, Mbaebie B. Phytochemical constituents of some Nigerian medicinal plants. Afr J Biotechnol. 2005; 4: $685-88$.

Farre A, Colombo M, Fort M, Gutierrez B. Differential effects of various $\mathrm{Ca}^{+2}$ antagonists. Gen Pharmacol. 1991; 22: 177-81.

Fleckenstein-Grün G. Calcium antagonism in vascular smooth muscle cells. Pflug Arch Eur J Phy. 1996; 432: R53-60.

Gilani AH, Khan AU, Subhan F, Khan M. Antispasmodic and bronchodilator activities of St John's wort are putatively mediated through dual inhibition of calcium influx and phosphodiesterase. Fundam Clin Pharmacol. 2005; 19: 695705 .

Godfraind T, Miller R, Wibo M. Calcium antagonism and calcium entry blockade. Pharmacol Rev. 1986; 38: 321-416.

Hussain S, Jamil M, Ullah F, Khan A, Ullah F, Arfan M, Ahmad S, Khatoon L. Antimicrobial and anti-oxidant activities of the plant Heliotropium strigosum. Afr J Biotechnol. 2010; 9: 7738-43.

Janbaz KH, Javed S, Saqib F, Imran I, Zia-Ul-Haq M, De Feo V. Validation of ethnopharmacological uses of Heliotropium strigosum Willd. as spasmolytic, bronchodilator and vasorelaxant remedy. BMC Complement Altern Med. 2015; 15: 169 .

Kai L, Wang ZF, Xiao JS. L-type calcium channel blockade mechanisms of panaxadiol saponins against anoxic damage of cerebral cortical neurons isolated from rats. Zhongguo Yao Li Xue Bao. 1998; 19: 455-58.

Karaki H, Weiss GB. Calcium release in smooth muscle. Life Sci. 1988; 42: 111-22.

Khan H, Khan MA, Hussain S, Gaffar R, Ashraf N. In vivo antinociceptive and anticonvulsant activity of extracts of Heliotropium strigosum. Toxicol Ind Health. 2013; 12: 1176-77.

Mattocks A. Strigosine, major alkaloid of Heliotropium strigosum. J Chem Soc. 1964; 10: 1974-77.

Modak B, Rojas M, Torres R, Rodilla J, Luebert F. Antioxidant activity of a new aromatic geranyl derivative of the resinous exudates from Heliotropium glutinosum Phil. Molecules 2007; 12: 1057-63.

Parekh J, Chandana S. In vitro antimicrobial activity of Trapa natans L. Fruit rind extracted in different solvents. Afr J Biotechnol. 2007; 6: 766-70.

Patel SS, Verma NK, Ravi V, Gauthem K, Sony N. Antihypertensive effects of an aqueous extract of Passiflora nepalensis Wall. Int. J Appl Res Nat Prod. 2010; 3: 22-27.

Qayyum A, Sarfraz RA, Ashraf A, Shazia A. Phenolic composition and biological (antidiabetic and anti-oxidant) activities of different solvent extracts of an endemic plant (Heliotropium strigosum). J Chil Chem Soc. 2016; 61: 1.

Rafique N, Khan T, Shah A. Calcium entry blocking activity of the Elaeagnus umbellata fruit extract explains its use in diarrhea and gut spasm. Bangladesh J Pharmacol. 2016; 11: 585-92.

Rahman MM, Wahed MII, Biswas MHU, Sadik GMG, Haque ME. In vitro antibacterial activity of Trapa bispinosa Roxb. J Med Sci. 2001; 1: 214-46.

Shah AJ, Bhulani NN, Khan SH, Gilani AH. Calcium channel blocking activity of Mentha longifolia L. explains its medicinal use in diarrhoea and gut spasm. Phytother Res. 2010; 24: 1392-97.

Van Rossum JM. Cumulative dose-response curves. II. Techniques for the making of dose-response curves in isolated organs and the evaluation of drug parameters. Arch Int Pharmacodyn Ther. 1963; 143: 299-30.

Zhu F, Huang B, Hu CY, Jiang QY, Lu ZG, Lu M, Wang MH, Gong M, Qiao CP, Chen W, Huang PH. Effects of total flavonoids of Hippophae rhamnoides L. on intracellular free calcium in cultured vascular smooth muscle cells of spontaneously hypertensive rats and Wistar-Kyoto rats. Chin J Integr Med. 2005; 11: 287-92.

Zhu M, David PJ, Greengrass PM, Bowery NE, Cai Y. Plant polyphenols: Biologically active compounds or non-selective binders to protein? Phytochemistry 1997; 44: 441-47.

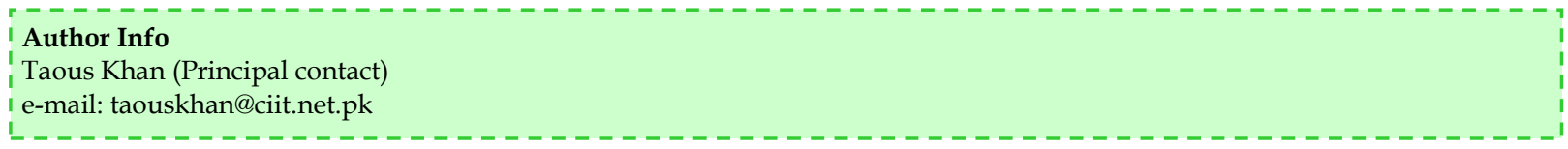




\section{Your feedback about this paper}

1. Number of times you have read this paper 0

2. Quality of paper Click

3. Your comments

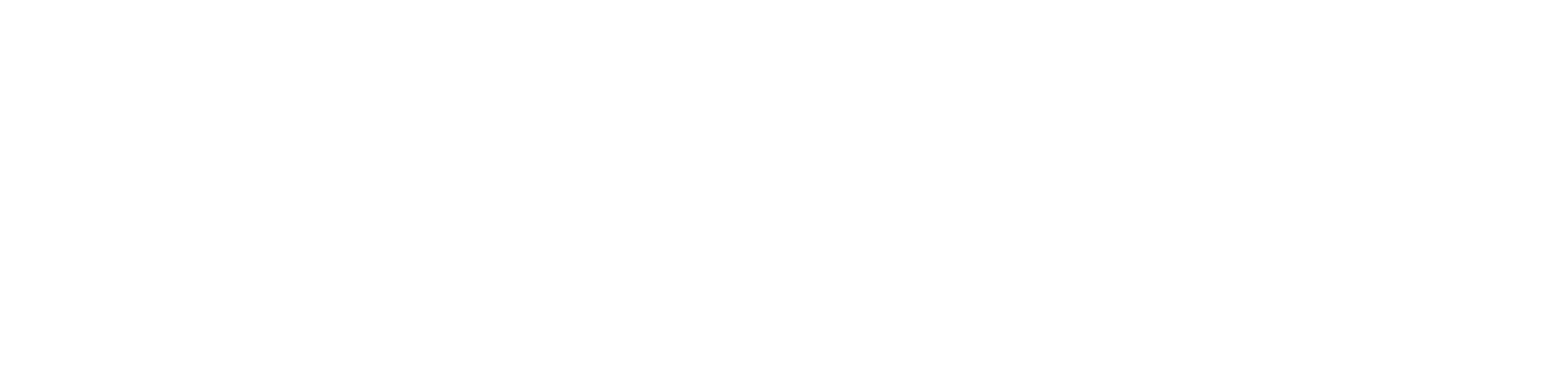

